\title{
nature
} structural \&
molecular biology

\section{A tribute to a very special scientist}

$\mathbf{T}$ he headline on 28 October 2007 in the New York Times read: "Arthur Kornberg, 89, Dies; Won Nobel for DNA Work."

Once I had read the obituary several times over I started to think about how I could best honor Arthur. After several e-mails and phone calls with my good friend and fellow graduate from the Biochemistry Department at Stanford University, Tania Baker, we came up with the idea of asking close colleagues to contribute their thoughts and recollections about Arthur. These reminiscences would be compiled and published together, along with photos, as a permanent record and tribute to Arthur in the pages of Nature Structural \& Molecular Biology.

After all, there had already been and would be many obituaries written about Arthur. All the facts about his educational history and scientific accomplishments would be recounted many times over. Kornberg was born in Brooklyn, New York on 3 March 1918 and was educated in its public schools. He went to the City College of New York at the age of 15. He received his medical degree from the University of Rochester in 1941. He worked at the US National Institutes of Health from 1942 to 1952, taking time out to study at New York University with Severo Ochoa, with whom Kornberg shared the Nobel Prize in Physiology or Medicine in 1959. In 1953 Kornberg became the chairman of the Department of Microbiology at Washington University in St. Louis. He started a Department of Biochemistry at Stanford University in 1959, serving as its chairman until 1969 and thereafter as professor. He accepted the title of Professor Emeritus in 1988 and remained active in the lab until his death on Friday, 26 October 2007.
But how much do these facts tell you about Arthur? Even if you were to read his every paper (there are over 400 of them) and every book (there are six of them, including two editions of DNA Replication), how much closer would you be to knowing anything about what he was really like?

So I wrote to as many colleagues as I could think of-those of you who knew Arthur as a mentor, teacher, coauthor, collaborator, competitor, advisor, scientist, department leader and last, but not least, as a friend, and I asked you to share a personal story about Arthur. I was certain about one thing: few people who had ever met him forgot the experience. Now all I had to do was convince you to tell me (and our readers) about those experiences.

It turned out to be quite easy-the stories just started pouring in. They tell us about Arthur the consummate biochemist and the demanding advisor; they illustrate his commitment to excellence and his impatience for wasted time; they recount his 'Ten Commandments of Enzymology' and his important $11^{\text {th }}$ addition, "Thou shalt support basic research!". The stories give us a picture of a man who was passionate about the science and the people who did the work. He was strong willed and had a singular vision about how things should be done- how many people do you know that could convince all the lab heads in a department to share space, equipment and grants?

In writing these remembrances of Arthur, we have all tried to capture a bit of what he was like, and what working with him meant to us, in the hope that those who knew him will have even richer memories to share and - more importantly—-those who didn't know him will get a glimpse of him through our memories. To my mind it is these personal stories (and many more like them) that will be his longest-lasting legacy.

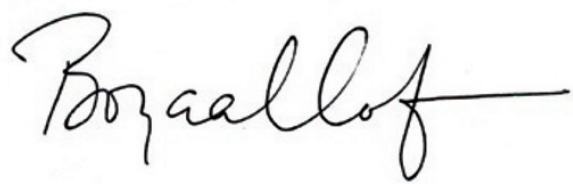

